\title{
Recovery of Bacillus sphaericus Flocculation/Sedimentation and Flotation
}

\author{
Christine Lamenha Luna ${ }^{1 *}$, Carlos Edison Lopes ${ }^{2}$ and Giulio Massarani ${ }^{1}$ \\ ${ }^{I}$ Programa de Engenharia Química; COPPE; Universidade Federal do Rio de Janeiro; Cidade Universitária; \\ C. P. 68502; 21945-970; - Rio de Janeiro - RJ - Brasil. ${ }^{2}$ Departamento de Antibióticos; Universidade Federal de \\ Pernambuco; Av. Prof. Moraes Rego, 1235; Cidade Universitária; 50670-901; Recife - PE - Brasil
}

\begin{abstract}
The aim of this work was use flocculation/sedimentation and flotation for recovery of spores of the Bacillus sphaericus. Microorganism was produced batchwise using culture medium based skimmed milk, corn steep liquor and mineral salts. The best results of flocculation were obtained using $\mathrm{CaCl}_{2} .2 \mathrm{H}_{2} \mathrm{O}, \mathrm{FeCl}_{3} .6 \mathrm{H}_{2} \mathrm{O}, \mathrm{Al}_{2}\left(\mathrm{SO}_{4}\right)_{3}$ and tannin as flocculating agents, with optimal flocculation concentrations of 1,500, 3,000, 2,000 and 1,700ppm, respectively. Flocculent suspensions were characterized based on floc diameter and density. Settling tests were performed in batch at different concentrations of the cellular suspensions and revealed high recovery of the solids in suspension in all cases. Flotation tests were accomplished using a mechanical agitated flotation cell and the process was favoured by the increase of the system agitation and for the presence of a cationic collector.
\end{abstract}

Key words: Bacillus sphaericus, flocculation, sedimentation, flotation

\section{INTRODUCTION}

The indiscriminate use of the chemical defensives and its harmful consequences to the environment had stimulated the development of techniques of biological control of harmful insects, in agriculture and public health. Bacteria of the genus Bacillus are among entomopathogenic microorganisms more utilized, especially for its capacity to form spores and toxins of high specificity to insects. Bacillus sphaericus is used in programs of control of mosquitoes of the genus Anopheles and Culex, vectors of endemic diseases as malaria and filariasis, respectively. The varieties most toxic to the larvae of mosquitoes, including the strain 2362, produce a crystal composed for two proteins of 51.4 and $41.9 \mathrm{kDa}$. Both the proteins are required for the toxic action and are produced during sporulation stage. The crystal remains associated to spore, being this complex (spore and crystal) contained in the exosporium (Charles et al., 1997).

The flocculation/sedimentation processes constitute one of the main alternatives of cells recovery in suspension. It is a phenomenon of great biotechnological interest, since it makes possible the use of settles at industrial scale. On the other hand, the bacterial cells possess a natural trend of adhering to the air bubbles during the submerged and aerated fermentative processes that suggests the possibility of use of flotation for biomass recovery. It is a well-established procedure of separation in mineral technology and also used for the recovery of diverse types of biological materials (Rios, 1998).

\footnotetext{
*Author for correspondence
} 
In this work, the use of flocculation/sedimentation and flotation were evaluated for the separation of biomass of $B$. sphaericus 2362, allowing the accomplishment of concentrated materials that were the base for the preparation of formulated bio-insecticides.

\section{MATERIALS AND METHODS}

\section{Microorganism}

Bacillus sphaericus 2362 was used in this study. The culture was maintained as spores on surface paper filter discs containing $1.3 \times 10^{6}$ spores per disc and stored at $4^{\circ} \mathrm{C}$.

\section{Growth medium}

The growth medium was proposed by Rios (1998). The medium composition, in $\mathrm{g} / \mathrm{L}$ : skimmed milk 20.0; corn steep liquor 25.0; $\mathrm{KH}_{2} \mathrm{PO}_{4} \quad$ 1.0; $\mathrm{MgSO}_{4} .7 \mathrm{H}_{2} \mathrm{O} 0.1 ; \mathrm{CaCl}_{2} .2 \mathrm{H}_{2} \mathrm{O} 0.1 ; \mathrm{FeSO}_{4} \cdot 7 \mathrm{H}_{2} \mathrm{O}$ $0.01 ; \mathrm{MnSO}_{4} . \mathrm{H}_{2} \mathrm{O} 0.01 ; \mathrm{ZnSO}_{4} .7 \mathrm{H}_{2} \mathrm{O} 0.01$.

\section{Fermentation conditions}

The inoculum was prepared in Fernbach flasks containing $250 \mathrm{~mL}$ of medium and one paper filter disc impregnated with the sporulated culture. The growth was performed during 12 to 15 hours, at $200 \mathrm{rpm}, 30^{\circ} \mathrm{C} \pm 1{ }^{\circ} \mathrm{C}$. The inoculum size was $5 \%$ $(\mathrm{v} / \mathrm{v})$. Fermentation was carried out in batch using a bioreactor (New Brunswick Company FS-14) with $10 \mathrm{~L}$ of culture medium, at 200rpm, 1vvm, $30^{\circ} \mathrm{C} \pm 1{ }^{\circ} \mathrm{C}$, for $48 \mathrm{~h}$.

\section{Optimal concentration of flocculating agent}

Flocculation assays were performed through jar test (Milan JT103), and the flocculation and efficiency of solids recuperation were evaluated in presence of $\mathrm{NaCl}, \mathrm{CaCl}_{2} \cdot 2 \mathrm{H}_{2} \mathrm{O}, \mathrm{FeCl}_{3} \cdot 6 \mathrm{H}_{2} \mathrm{O}$, $\mathrm{Al}_{2}\left(\mathrm{SO}_{4}\right)_{3}$, tannin (Tanfloc SG) and a cationic polyacrylamide (Polyfloc CP1600P).

The flocculating agent was added to the suspension under an agitation of 90rpm during 5 minutes; then, the intensity of agitation was reduced to 40rpm during 10 minutes for the flocs formation. The suspension was maintained at rest for the observation of flocs sedimentation and the quality of the clarified liquid.

Solids recovery $(R \%)$ was determined by the Equation 1, where $C_{T}$ is the total solids concentration in the suspension and $C_{S}$ is the solids concentration in the supernatant fluid. Samples were collected in the supernatant when the height interface was corresponding to $20 \%$ of the total suspension height. The experiments were realized in duplicate.

$$
R(\%)=\left(\frac{C_{T}-C_{S}}{C_{T}}\right) \times 100
$$

\section{Settling tests}

Kynch's methodology (1952) was employed for the settling tests, based on the observation of the displacement of the upper interface of the suspension with time. Tests were performed in measuring cylinders of $500 \mathrm{~mL}$ of capacity, height of $36.2 \mathrm{~cm}$ and diameter of $5.4 \mathrm{~cm}$, with suspensions at different cellular concentrations.

Settling velocity was calculated by the slope of the linear section in the sedimentation curve, and the recovery efficiency was determined by the Equation 1. Samples were collected in the supernatant fluid when the height interface was corresponding to $20 \%$ of the suspension height or at the end of sedimentation for the more concentrated suspensions.

\section{Flocs characterization}

Flocs density and fluid volumetric fraction: Flocs density $\left(\rho_{f l}\right)$ was determined by the centrifugation technique as described by França (2000). This methodology allows determining the fluid volumetric fraction $\left(\varepsilon_{f}\right)$ by the Equation 2 :

$$
\varepsilon_{f}=\frac{V_{s}}{V_{t}}
$$

where $V_{s}$ is the supernatant volume and $V_{t}$ is the total volume of the suspension in the tube. The rotation velocity and the centrifugation time were determined visually to obtain a non-compacted sediment, with values of $250 \mathrm{rpm}$ and 5 minutes, respectively, for all the flocculent suspensions. Tests were performed in quadruplicate.

Flocs diameter: Flocs diameter $\left(D_{\mathrm{fl}}\right)$ was determined according to Massarani (2002) through the Equation 3:

$$
k=k\left(\varepsilon_{f}\right)=\frac{D_{f l}{ }^{2} \varepsilon_{f}{ }^{3}}{36 \beta\left(1-\varepsilon_{f}\right)^{2}}
$$


where $k$ is the medium permeability, calculated by the Equation 4:

$$
k\left(\varepsilon_{f}\right)=\frac{\mu_{f} v_{s}}{\left(1-\varepsilon_{f}\right)\left(\rho_{f l}-\rho_{f}\right) g}
$$

and $\beta$ is a parameter that depends on the porosity for the expanded particulated systems, determined through the Equations 5 e 6 :

$$
\begin{aligned}
& \beta=0.60 \frac{\left(\varepsilon_{f}{ }^{-1.94}\right)}{1-\varepsilon_{f}}, 0.5<\varepsilon_{f} \leq 0.9 \\
& \beta=\frac{\varepsilon_{f}{ }^{2}}{2\left(1-\varepsilon_{f}\right)\left(4.8 \varepsilon_{f}-3.8\right)}, 0.9<\varepsilon_{f}<1
\end{aligned}
$$

where $\mu_{f}$ is the fluid viscosity, $v_{s}$ is the settling velocity calculated at constant rate, $\rho_{f l}$ is the floc density, $\rho_{f}$ is the fluid density and $g$ is the gravitational acceleration.

\section{Flotation}

Flotation tests were carried out in a mechanical agitated flotation cell (Outokumpu) using vessel with $2 \mathrm{~L}$ of capacity. The influence of addition of a cationic collector (commercial amine Flotigam 3135B) and the agitation were evaluated on the recuperation percentage and the concentration factor spores. Flotation was carried out for 20 minutes and samples were collected in the residual liquid during the process. Foam was received on trays. Spores concentration on the foam $\left(X_{F}\right)$ was determined by the Equation 7:

$$
X_{F}=\frac{\left(V_{0} \times X_{0 E}\right)-\left(V_{R} \times X_{R}\right)}{\left(V_{0}-V_{R}\right)}
$$

where $V_{0}$ is the initial volume of flotation (2L), $X_{O E}$ is the spores concentration on the fermented broth, $V_{R}$ and $X_{R}$ are the volume and the spores concentration on the residual liquid after the flotation, respectively.

Recovery percentage (\%Rec) and the concentration factor spores $(F C)$ were determined through the Equations 8 and 9, respectively:

$$
\begin{aligned}
& \% \operatorname{Re} c=\left[\frac{\left(V_{0}-V_{R}\right) \times X_{F}}{\left(V_{0} \times X_{0 E}\right)}\right] \times 100 \\
& F C=\frac{X_{F}}{X_{0 E}}
\end{aligned}
$$

\section{Analytical methods}

Cell concentration in the suspension: was determined by dry weight at $105^{\circ} \mathrm{C}$, after filtration of the samples using membranes of $0.45 \mu \mathrm{m}$.

Viable spores concentration: was determined through counting of colonies grown on the surface of plates of Petri containing agar nutrient, after thermal shock $\left(80^{\circ} \mathrm{C}, 12 \mathrm{~min}\right)$. The colonies were counted and express in Colonies Formation Units per $\mathrm{mL}(\mathrm{CFU} / \mathrm{mL})$.

\section{RESULTS AND DISCUSSION}

$\mathrm{NaCl}$ did not induce the flocs formation, while the polyacrylamide polymer presented a flocculation with small dispersed filaments, without possibility of visualization of the sedimentation front. Fig. 1 shows the results for the flocculation tests. Optimal concentration of flocculating agents were $1,500, \quad 3,000, \quad 2,000$ and 1,700ppm for $\mathrm{CaCl}_{2} \cdot 2 \mathrm{H}_{2} \mathrm{O}, \mathrm{FeCl}_{3} \cdot 6 \mathrm{H}_{2} \mathrm{O}, \mathrm{Al}_{2}\left(\mathrm{SO}_{4}\right)_{3}$ and tannin, respectively, with average indices of recovery around $100 \%$ for all the cases.

Figs. 2 and 3 show the settling curves for the flocculent suspensions, and the Fig. 4 shows the maximum settling velocities in function of the solids concentration in suspension.

Table 1 illustrates the results of density and average diameter of flocs.

For solid concentrations above $1.8 \mathrm{~g} / \mathrm{L}$, the biggest velocities were obtained for flocs with $\mathrm{CaCl}_{2} \cdot 2 \mathrm{H}_{2} \mathrm{O}$ (5.2 to $0.4 \mathrm{~cm} / \mathrm{min}$ for concentrations between 1.8 and $7.0 \mathrm{~g} / \mathrm{L}$ ), what coincided with the major value for the average diameter $(275.6 \mu \mathrm{m} \pm$ $9.5 \mu \mathrm{m})$. Fig. 4 showed a more accented variation with the concentration until about $4.5 \mathrm{~g} / \mathrm{L}$, when the velocity tended to stabilize.

Flocs with tannin presented high values of velocity for concentrations below $1.4 \mathrm{~g} / \mathrm{L}$. Although to present the biggest density, they sedimented more slowly than flocs with $\mathrm{CaCl}_{2} \cdot 2 \mathrm{H}_{2} \mathrm{O}$, perhaps for presenting a smaller average diameter.

Flocculent suspensions with $\mathrm{FeCl}_{3} \cdot 6 \mathrm{H}_{2} \mathrm{O}$ and $\mathrm{Al}_{2}\left(\mathrm{SO}_{4}\right)_{3}$ presented similar profiles of velocity, 
with values varying between $4.0-0.35 \mathrm{~cm} / \mathrm{min}$ and $3.1-0.3 \mathrm{~cm} / \mathrm{min}$ for concentrations of 0.8 to $3.8 \mathrm{~g} / \mathrm{L}$ and 1.5 to $5.0 \mathrm{~g} / \mathrm{L}$, respectively. In these cases, similar values were obtained for density and average diameter of flocs.

According to the Fig. 5, the values for cells recovery for the suspension in presence of $\mathrm{Al}_{2}\left(\mathrm{SO}_{4}\right)_{3}$ was between 83 and $86 \%$, following the flocs with $\mathrm{FeCl}_{3} \cdot 6 \mathrm{H}_{2} \mathrm{O}$ (86 to $91 \%$ ), $\mathrm{CaCl}_{2} \cdot 2 \mathrm{H}_{2} \mathrm{O}$ (89 to $95 \%$ ) and tannin (96 to $100 \%$ ).

Fig. 6 shows the results of kinetics of removal of the spores using mechanical agitated flotation cell. For a concentration of the collector of 200ppm was obtained low spores recovery with the agitated system at 832 and $960 \mathrm{rpm}$, with residual values stabilizing around 35\% after 20 minutes of process.

An increase in the concentration of the collector for 400ppm improved the efficiency of spores recovery, with residual value corresponding to
$16 \%$ for $832 \mathrm{rpm}$, while that only $3.5 \%$ of the spores remained in the residual liquid for the agitated system at $960 \mathrm{rpm}$. Using 600ppm of the collector, about $13 \%$ of residual spores were observed for an agitation of 832rpm after 20 minutes of flotation.

An agitation of 960rpm resulted a recovery of $100 \%$ for a flotation time of only 5 minutes. The results indicated that the increase of the concentration of the collector and the system agitation improved the kinetic of spores removal. Despite the recognized hydrophobic nature of spores in species of Bacillus, (Stabnikowa et al., 1991), some constituent of culture media containing solids of diverse natures, such as the medium used in this work, could recover the spores and reduced its characteristic of floatability.

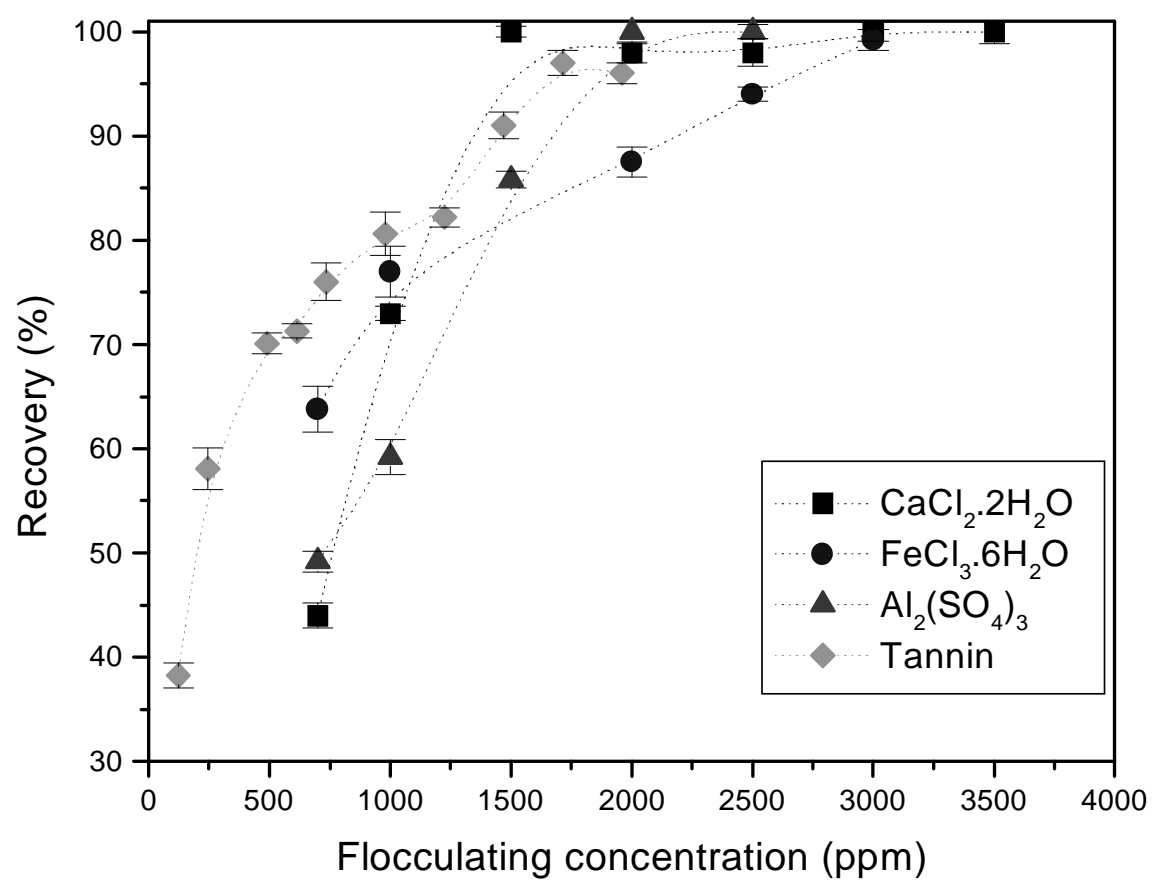

Figure 1 - Effect of the addition of the flocculating agents on the cells recovery. 

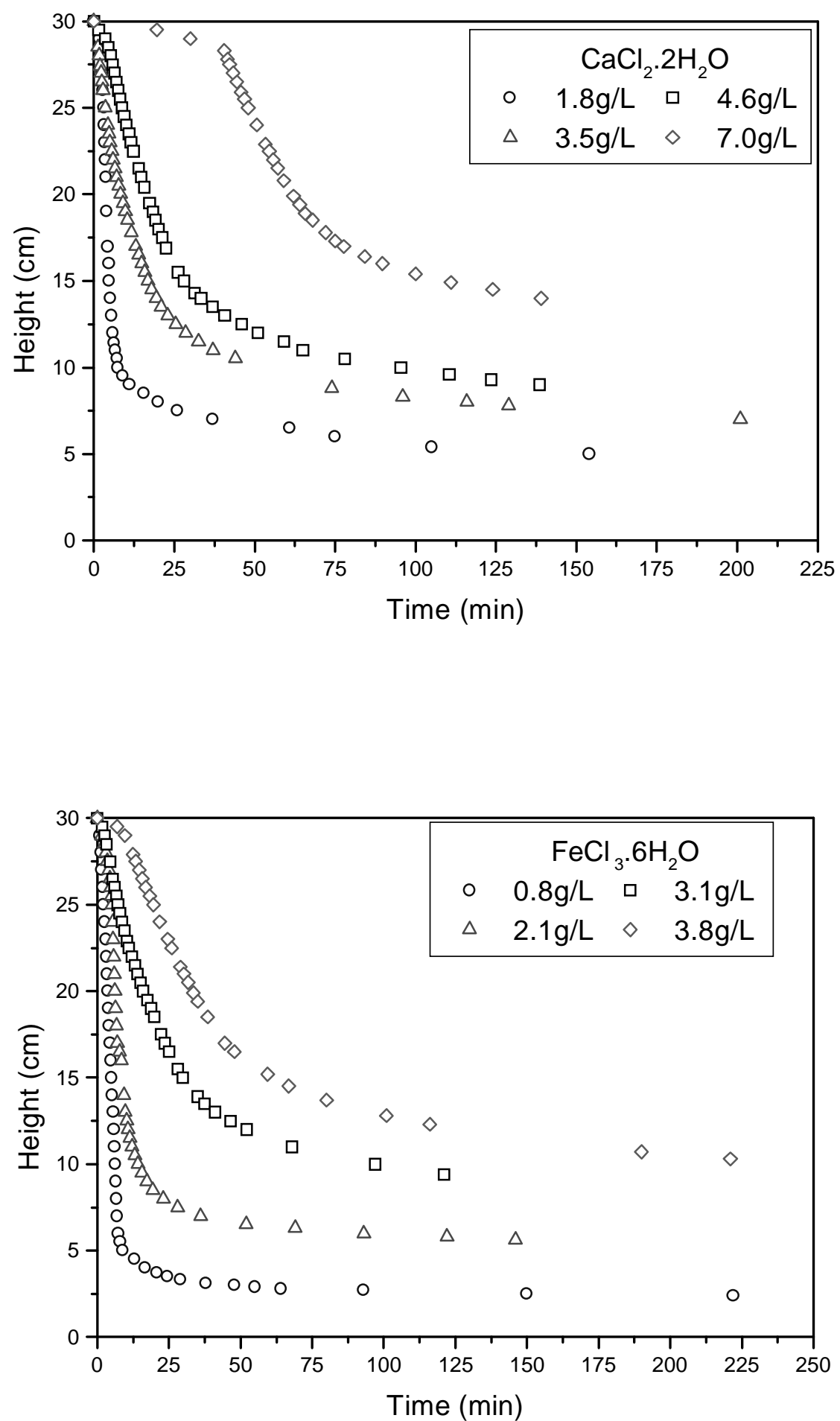

Figure 2 - Flocs sedimentation curves of B. sphaericus using 1,500ppm of $\mathrm{CaCl}_{2} \cdot 2 \mathrm{H}_{2} \mathrm{O}$ and 3,000ppm of $\mathrm{FeCl}_{3} \cdot 6 \mathrm{H}_{2} \mathrm{O}$. 

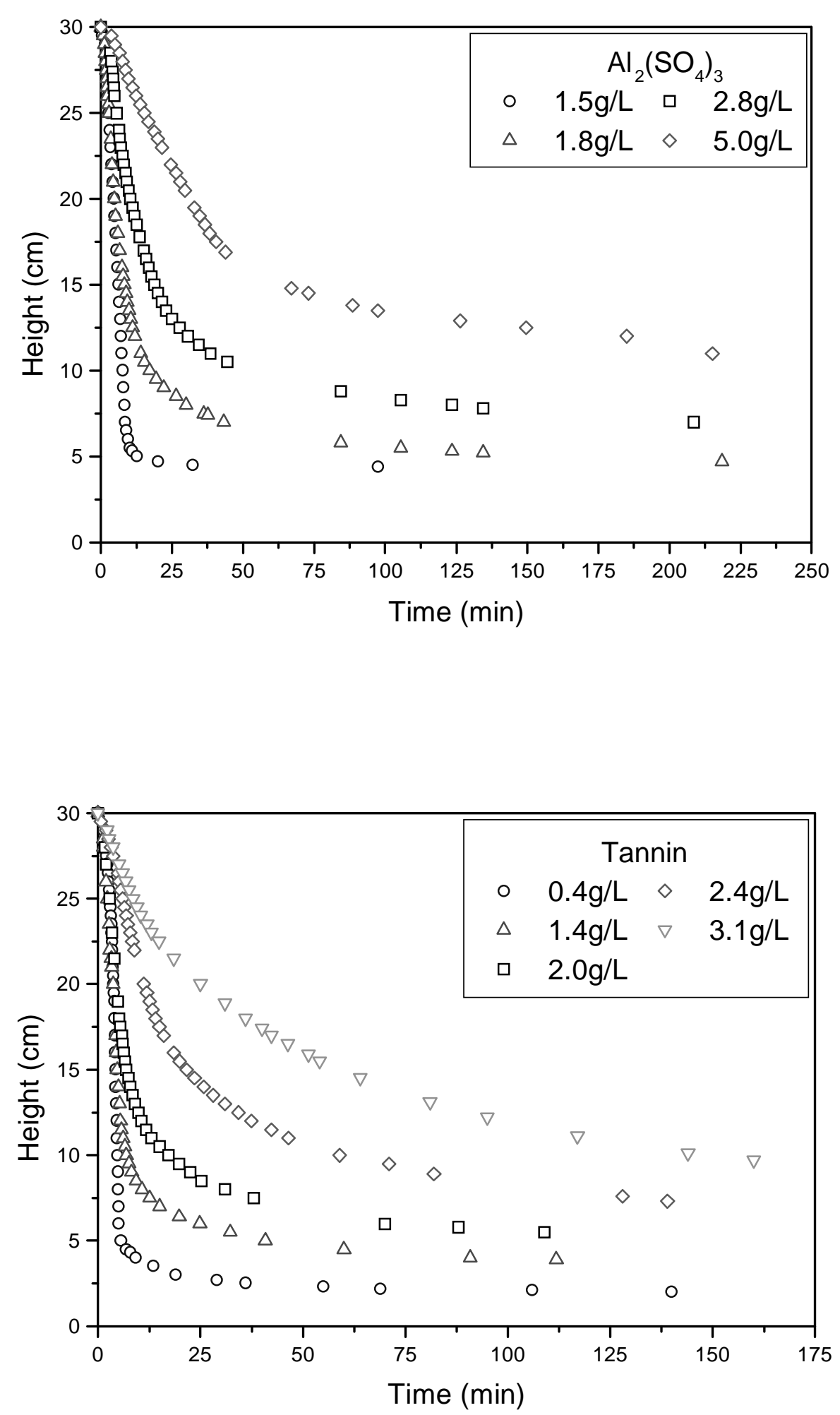

Figure 3 - Flocs sedimentation curves of $B$. sphaericus using 2,000ppm of $\mathrm{Al}_{2}\left(\mathrm{SO}_{4}\right)_{3}$ and $1,700 \mathrm{ppm}$ of tannin. 


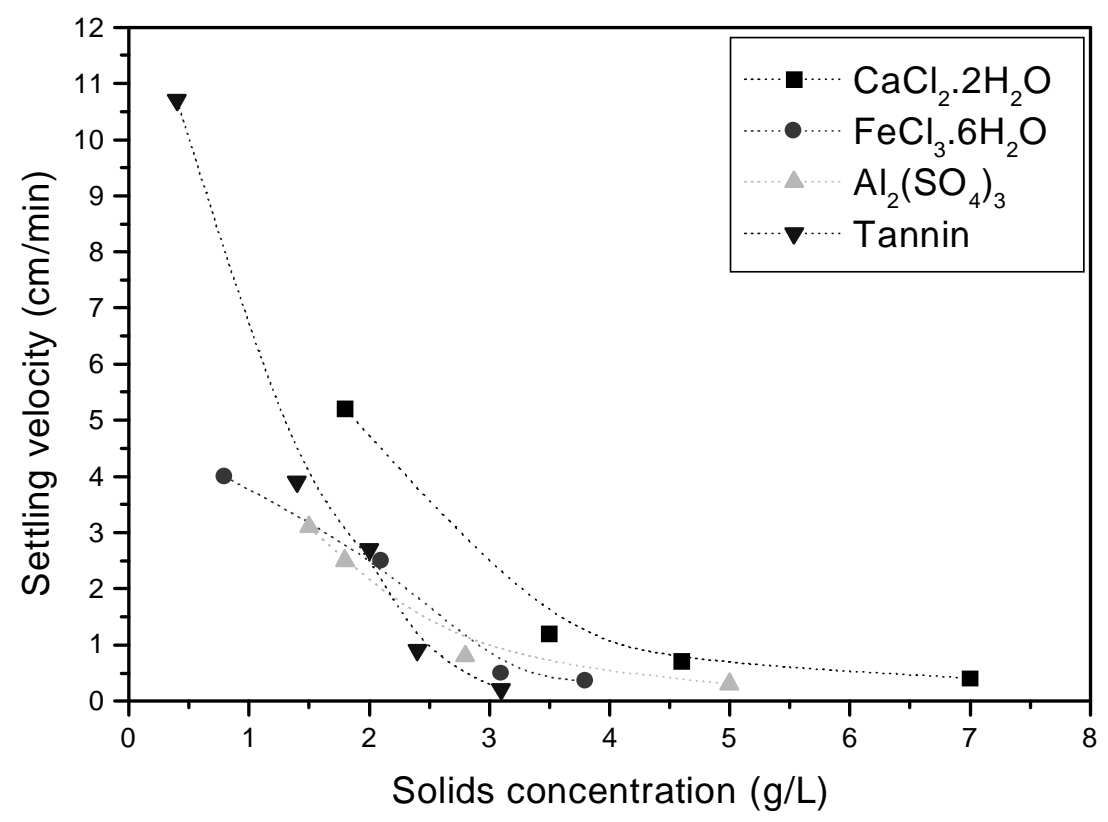

Figure 4 - Settling velocities of the flocculent suspensions of B. sphaericus.

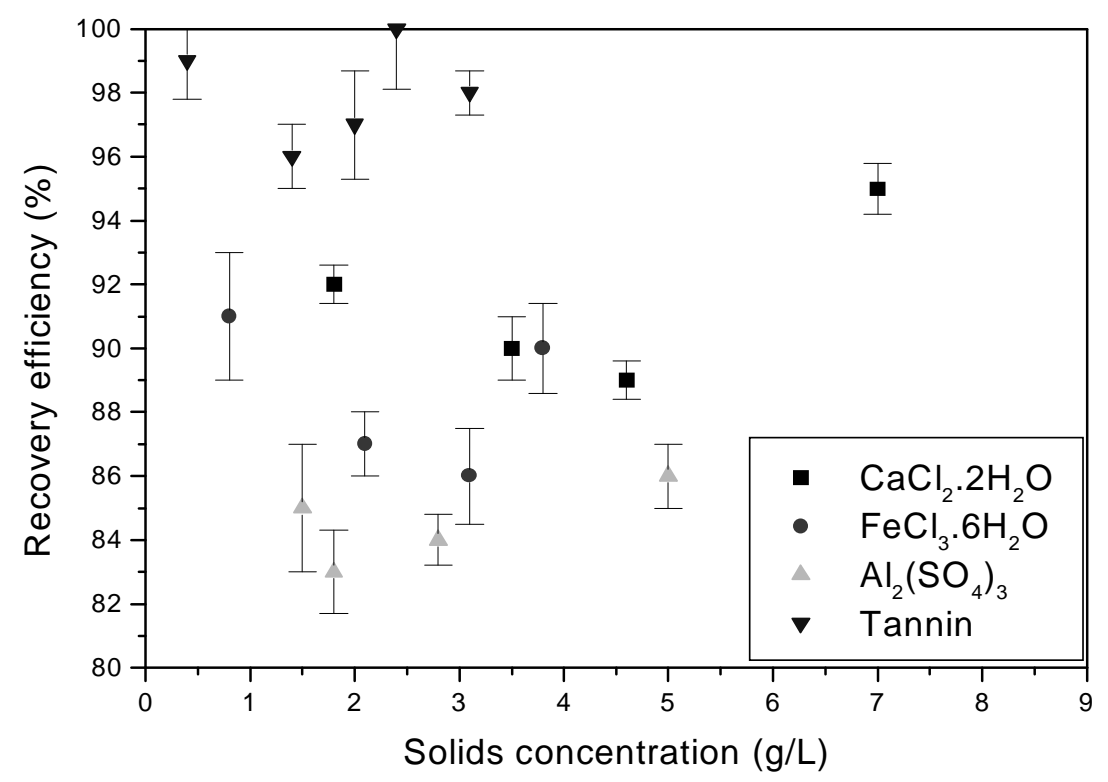

Figure 5 - Efficiency of cell recovery for the flocculent suspensions. 
Table 1 - Results of density and average diameter of flocs.

\begin{tabular}{lcc}
\hline \multicolumn{1}{c}{ Flocculating agent } & $\boldsymbol{\rho}_{f l}\left(\mathbf{g} / \mathbf{c m}^{3}\right)$ & $\boldsymbol{D}_{f l}(\boldsymbol{\mu} \mathbf{m})$ \\
\hline $\mathrm{CaCl}_{2} .2 \mathrm{H}_{2} \mathrm{O}$ & $1.102 \pm 0.025$ & $275.6 \pm 9.5$ \\
$\mathrm{FeCl}_{3} \cdot 6 \mathrm{H}_{2} \mathrm{O}$ & $1.100 \pm 0.020$ & $114.8 \pm 8.9$ \\
$\mathrm{Al}_{2}\left(\mathrm{SO}_{4}\right)_{3}$ & $1.101 \pm 0.020$ & $132.4 \pm 11.4$ \\
Tannin & $1.140 \pm 0.060$ & $157.8 \pm 29.6$ \\
\hline
\end{tabular}

Fig. 7 shows the results of the recovery percentage and the concentration factor of spores. The highest recoveries had been observed for the concentrations of the collector of 400 and $600 \mathrm{ppm}$ at 960rpm (98\%), following of the agitated system at $832 \mathrm{rpm}(94 \%)$. The minor value was observed for 200ppm of the collector in both the agitations, corresponding to $77 \%$ of efficiency of spores removal.

Although recovery percentages values were equivalents for the experiments of same concentration of the collector, variations were observed in the values of concentration factor of spores. For the conditions of 400ppm and 600ppm, the major spore concentration had been observed in the agitated system at 960rpm. In addition, the highest values of concentration factor of spores were observed for $400 \mathrm{ppm}$ of collector (3.0 and 2.6), which could be explained by the minor drags of liquid for the foam observed in these cases.

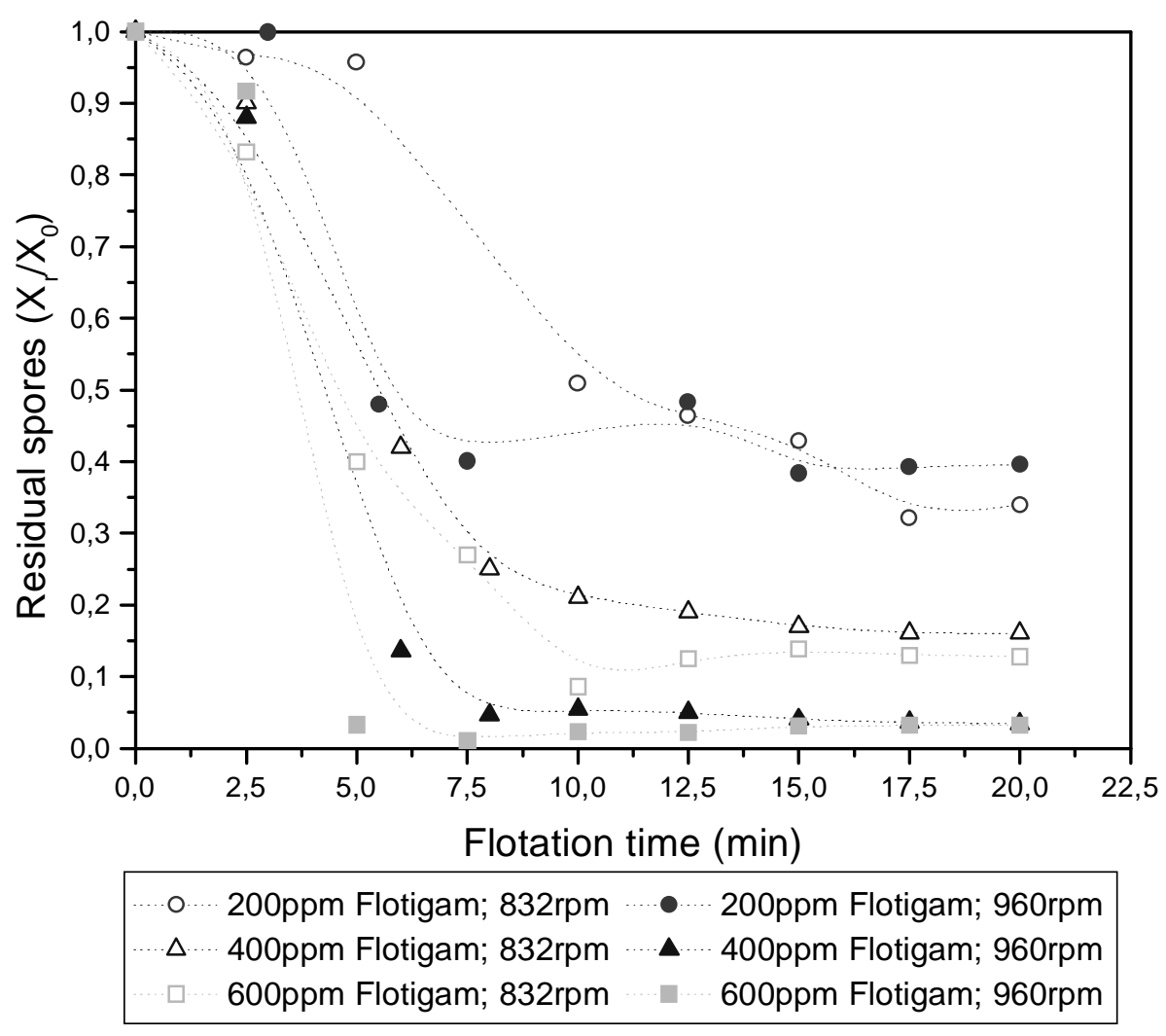

Figure 6 - Fraction of residual spores of B. sphaericus (6L air/min; $\mathrm{pH} 7$ ). 

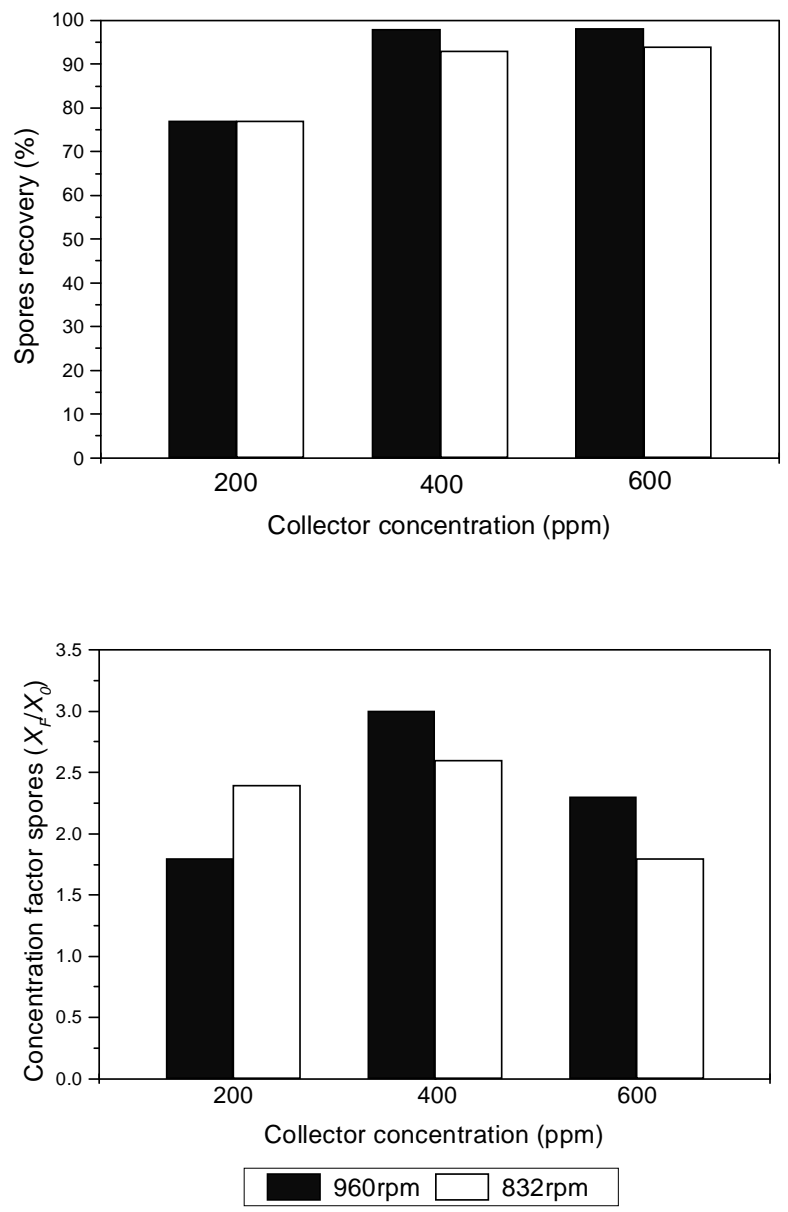

Figure 7 - Recovery percentage and the concentration factor spores $(6 \mathrm{~L} / \mathrm{min} ; \mathrm{pH} 7)$

\section{ACKNOWLEDGEMENTS}

Authors thank to CNPq, for the financial support, and to Laboratório de Tecnologia Mineral, for the use of the mechanical agitated flotation cell.

This work is dedicated to memory of professor Giulio Massarani.

\section{RESUMO}

O trabalho aborda a recuperação de esporos da bactéria Bacillus sphaericus por floculação/sedimentação e flotação. $\mathrm{O}$ microrganismo foi produzido em batelada, utilizando-se meio de cultivo à base de leite desnatado, milhocina e sais minerais. Os melhores resultados de floculação foram obtidos com os floculantes $\mathrm{CaCl}_{2} \cdot 2 \mathrm{H}_{2} \mathrm{O}, \mathrm{FeCl}_{3} \cdot 6 \mathrm{H}_{2} \mathrm{O}, \mathrm{Al}_{2}\left(\mathrm{SO}_{4}\right)_{3} \mathrm{e}$ tanino, com concentrações ótimas de 1.500, 3.000, 2.000 e $1.700 \mathrm{ppm}$, respectivamente. Os sistemas floculentos foram caracterizados através da determinação da densidade e do diâmetro médio dos flocos. Testes de sedimentação em batelada a diferentes concentrações das suspensões celulares revelaram elevados índices de recuperação dos sólidos em suspensão em todos os casos. Os ensaios de flotação foram realizados em célula de flotação mecânica, e o processo foi favorecido pelo aumento da agitação do sistema e pela presença de um coletor catiônico. 


\section{REFERENCES}

Charles, J. F.; Silva-Filha, M. H.; Nielsen-LeRoux, C.; Humphreys, M. J. and Berry, C. (1997), Binding of the 51- and 42-kDa individual components from the Bacillus sphaericus crystal toxin to mosquito larval midgut membranes from Culex and Anopheles sp. (Diptera: Culicidae). FEMS Microbiol. Lett., 156, 153-159.

França, S. C. A. (2000), Equações constitutivas para a sedimentação de suspensões floculentas. PhD Thesis, PEQ/COPPE, Federal University of Rio de Janeiro, Rio de Janeiro, Brasil.

Kynch, G. J. (1952), A theory of sedimentation. Trans. Faraday Soc., 48, 166-176.

Massarani, G. (2002), Fluidodinâmica em sistemas particulados. E-papers, Rio de Janeiro.

Rios, E. M. (1998), Recuperação de esporos de Bacillus sphaericus em meio fermentado. $\mathrm{PhD}$ Thesis, Chemical School, Federal University of Rio de Janeiro, Rio de Janeiro, Brasil.

Stabinikova, E. V.; Gregirchak, N. N. and Taranenko, T. O. (1991), Flotation characteristics of bacillary cells and spores. Mikrobiologicheskii Zhurnal, 53, 38-42. 